\title{
Burning Questions: Spontaneous Human Combustion in Early Modern Europe*
}

Michael R. Lynn

\section{Summary}

Spontaneous human combustion shocked and confused people in early modern France. Without a body to examine or eyewitness reports savants had difficulty determining its causes. Nonetheless, people like Claude-Nicolas Le Cat and Pierre-Aimé Lair, sought to determine the causes of these events and provide a logical explanation for their appearance. This article analyzes the various arguments used by scholars to help rationalize a phenomenon that was simultaneously a medical conundrum and a holdover from the age of marvels and wonders.

Keywords: spontaneous human combustion, Claude-Nicolas Le Cat, Pierre-Aimé Lair, wonders, Enlightenment

Jean Millet and his wife Jeanne Lemaire went to bed as usual on the night of 19 February 1725. However, she got out of bed about ten o'clock p.m. and left the room, presumably to go and warm her feet by the fire in the kitchen. When Jean awoke a few hours later, he found his wife still absent from the room and, at the same time, he smelled a vile odor in the air. He crossed the short hallway to the kitchen where he found his wife dead. What was left of her lay about a foot and a half from the fire, but what was left was little enough; she had burned to death leaving behind only part of her head and a portion of her lower extremities along with some vertebrae and a few other bits and pieces. He quickly called a servant who poured water over the body, but it was far

* The author would like to thank KR Johnson, Judy Lynn, Maarten Ultee, and Kathleen Wellman for their help and comments.

Michael R. Lynn, Department of History and Philosophy, Purdue University Northwest, 1401 South US Highway 421, Westville, IN 46391, USA, Tel.: 1219 785-5380, mlynn@pnw.edu 
too late. The floor under the cadaver had been charred; a kneading board and a salt container near the body had not been touched. He later noted that the fire in the hearth had died down and the cinders had spread out. ${ }^{1}$

At first glance, the case appeared obvious to the local authorities. Millet was an innkeeper and merchant in Rheims with a wife described as perpetually drunk. Since his wife proved unable to perform her housework, Millet hired a pretty servant from Lorraine to help out. Millet, although described by one commentator as "one of the most honest men in the village," had received considerable attention for this household situation and his neighbors suspected an affair between him and his servant. Based on these circumstances, and with suspicious minds about Millet and the maid, the judges took the route most obvious to them; Jeanne Lemaire was dead and, presumably, her husband had wanted her out of the way. Therefore, it seemed extremely likely she had been murdered and the most likely suspect was surely her husband. Millet, the judges decided, had arranged for the seemingly accidental death of his wife. As one author wrote, "the pretty servant girl was the downfall of the poor Millet". 2 The judges found Millet guilty of murder. Only when he appealed his verdict to a higher court, one that recognized the possibility of spontaneous human combustion, was Millet declared innocent. However, the whole affair had a deleterious effect on his health and, "consumed by sadness" he "died in a hospital, an innocent victim of this phenomenon". ${ }^{3}$

The story of Millet, oft-repeated in the eighteenth century, gets its clearest telling in a posthumously published memoir written by Claude-Nicolas Le Cat, a medical doctor and surgeon who, as fate would have it, had stayed at Millet's inn for four or five months in late 1724 and early $1725 .{ }^{4}$ Indeed, he had only left a few days before Jeanne's death. Although not present himself, an area surgeon named Chrétien, along with some of Le Cat's other local friends, examined the remains of the body and, according to Le Cat, did so "with all the judicial formalities" which allowed them to make an exact analysis of the incident. In an age before the official status of the legal "scientific witness," Le Cat sets up his medical associates in Rheims to act the part of experts. ${ }^{5}$

In general, as Le Cat noted, the death of Jeanne Lemaire Millet greatly resembled that of other victims of spontaneous human combustion. He ob-

1 Le Cat 1813, 53-54.

2 Le Cat 1813, 55.

3 Le Cat 1813, 55.

4 Grise 2001.

5 Le Cat 1813, 53; Heilbron 1994. 
serves that the fire in the hearth was insufficient to result in the complete burning of a human body, especially since there were items right next to her that remained unaffected by the flames. In addition, Le Cat had made observations of burns caused by instruments and of people who had fallen into flames and died as a result; in neither of these cases were the bodies as completely consumed, as was the case with Madame Millet. In addition, it seemed as if the origin of the fire in Millet's case, according to the descriptions provided by his local experts, was inside her and near "the center of the body." For these reasons, Le Cat concluded, this was a case of spontaneous combustion. However, Le Cat lamented, what was obvious to him and to his friends present at the scene was less clear to the initial judges in the case. They could not see "the true cause" of the accident and so pursued their murder investigations. Only the later, more enlightened people who reviewed the case understood the true nature of this event and cleared Millet of all charges. As a result, Le Cat argued for educating the public on the reality of people dying in this fashion so they might recognize it in future. If only, Le Cat bemoaned, people better understood the laws of nature, and especially the laws that allowed such effects as spontaneous combustion, such a tragedy as the false accusation and subsequent death of Millet might not have happened. In an enlightened age, Le Cat believed, people would have recognized the horrible death of Jeanne Lemaire for what it was and the sad fate of Jean Millet would not have occurred. ${ }^{6}$

This essay will explore the ways in which authors explained the existence of spontaneous human combustion in early modern Europe, and especially France, from the earliest cases recorded there, in the second half of the seventeenth century, until the early nineteenth century. I argue that since they were unable to define the precise physical cause of this phenomenon, Le Cat and others seeking to analyze it instead sought to define the social conditions and personal habits that led to the possibility of being inflicted with spontaneous combustion. They then used the remains of the bodies to try and extrapolate information concerning the nature of the fire. In an age of reason, this phenomenon seemed to fall under the category of wonder or the marvelous. As such, a tension existed between those who reveled in the bizarre nature of the deaths and others who tried to compartmentalize and categorize those who may have died in this manner. Spontaneous combustion fell through the cracks of the Enlightenment and bridged the gap between the rational and the wondrous.

6 Le Cat 1813, 54-55. 
But where exactly does an account of spontaneous human combustion fit into the history of unusual, and possibly wondrous, phenomenon during the age of Enlightenment? Aside from a number of literary scholars focusing on a few nineteenth century authors - including, most infamously, Charles Dickens and his use of spontaneous combustion in the novel Bleak House but also others like Emile Zola in Le Docteur Pascal - this topic has received relatively little attention. ${ }^{7}$ It does not appear, for example, in the encyclopedic treatment of early modern French medicine by Laurence Brockliss and Colin Jones. ${ }^{8}$ Nor does it appear in other histories of eighteenth-century medicine. 9 A few studies have focused on the relationship between the legal and scientific aspects of this phenomenon. John Heilbron, for example, analyzed the role of emerging scientific expert witnesses involved in an alleged case of spontaneous combustion in the mid-nineteenth century. ${ }^{10}$

One of the possible reasons for the sparseness of contemporary academic interest in this topic stems from the relatively small number of cases available to study. Supporters of the idea of spontaneous combustion can only identify about a dozen cases during the period from about 1670 to 1800 although they gesture to a large number of similar occurrences from previous centuries that, at least in rough terms, seem to them to meet the necessary criteria. A topic more discussed than experienced, spontaneous human combustion sparked interest because of the difficulties in providing an explanation for what had occurred rather than because of its frequency. Without a body to examine afterward and little chance of diagnosing a potential case in advance, scholars at the time, including Le Cat, were at something of a loss as to how they should even approach the topic. Therefore, although the topic did receive notice in short articles published in scientific and medical journals during the eighteenth century, few scholars attempted to analyze the phenomenon as a whole.

The phenomenon does, however, fit neatly within the interest in wonders and the fascination people felt about a wide range of curious natural phenomena. As Lorraine Daston and Katherine Park have shown, intellectual interest in the wondrous abounded from the medieval period up to the age of Enlightenment. Savants throughout this longue durée of monsters and the

7 Dickens 1996; Josephson 1926; Wilkinson 1967; Blount 1970; Denman 1986; Gaskell 1972; Lewes 1861.

8 Brockliss and Jones 1997.

9 For example, Risse 1992; King 1958; Bondeson 1997.

10 Heilbron 1994. Cf. Adelson 1952. 
marvelous expressed a keen inclination to categorize and analyzed many of the events, strange animals, and peculiar people they happened upon or heard about. However, alongside the general decline in the intellectual justification for magic came a rise in skepticism of such wonders. As Daston and Park explain, this led intellectuals to "not so much debunk marvels as ignore them". ${ }^{11}$ This did not mean the end of interest in wondrous objects and people, but it did, they argue, mean a change in the way savants approached them. ${ }^{12}$ The fascination with the curious continued throughout the Enlightenment, but they became less of a focus of the philosophes and it fell to others to write on these topics. ${ }^{13}$

This could, in part, help explain why Le Cat's treatise on this subject appeared only after his death. Without a clear connection between spontaneous human combustion and the other debates of the day, Le Cat may not have intended its publication until he could clearly articulate his argument and link it with other medical theorizing prevalent in the eighteenth century. Other authors felt less compunction to hold back in this manner and certainly by the end of the eighteenth century, when France was occupied with debates over animal magnetism, divining rods, Tarot cards, and mermaids, the possibility of spontaneous human combustion might have seemed a more palatable topic on which to publish. ${ }^{14}$ These debates have led to what Simon Schaffer has recently argued was a "crisis of facts" that led people to question the distinctions between the wondrous and the scientific..$^{15}$

The natural philosopher and experimental demonstrator Joseph Aignan Sigaud de la Fond, for example, included a long entry on spontaneous combustion in his Dictionnaire des merveilles de la nature. Sigaud de la Fond, along with his nephew Rouland, spent most of his career as a popularizer of experimental physics. But he also dabbled in natural history and other subjects. He published his dictionary of marvels in 1781, just a short time after the moment Daston and Park have identified as the putative end to the legitimate scientific interest in wonders. Thus, his three-volume work serves as something of a throwback to the heyday of publishing on wonders found in previous centuries. In his essay on spontaneous combustion, Sigaud de la Fond formed a connection between all types of seemingly unprompted fires. Thus, in addition to his discussion of people who had died in this fashion, Sigaud de la Fond also noted a number of other examples including two sub-

11 Daston and Park 1998, 361.

12 Daston and Park 1998, 362.

13 Benedict 2001.

14 On Mesmerism see Belhoste and Edelman 2015; Darnton 1970; on divining rods see Lynn 2001; and on mermaids see Scribner 2017.

15 Schaffer 2018. 
terranean flash fires in Brest in 1741 and 1757. In addition, the entire village of Boncourt caught fire in 1670 "without any apparent cause" resulting in the loss of many houses. ${ }^{16}$

One of the most important arguments for spontaneous combustion came from Le Cat. Le Cat was a doctor who published a wide range of medical treatises during his lifetime. ${ }^{17} \mathrm{~A}$ founding member and later permanent secretary of the Académie des Sciences, Belles-Lettres et Arts de Rouen, Voltaire regarded him as an excellent physician but also as a "very great philosophe". ${ }^{18}$ Le Cat presented 170 communications to the Académie on a wide variety of topics. Two of these communications were on spontaneous combustion, although he was more famous in his lifetime for his work in areas such as urology and his work as a surgeon on kidney stones and cataracts. ${ }^{19}$ In between his other activities, Le Cat also found time to teach anatomy. ${ }^{20}$ He even got involved in the debate over Jean-Jacques Rousseau's First Discourse on the arts and sciences. ${ }^{21}$

His treatise discusses a number of instances of spontaneous combustion, but the strength of his argument rests on his intimate connection with the Millet case. In this essay, Le Cat begins by outlining the nature of the problem. He defines spontaneous combustion as a fire "which appears to ignite by itself." However, Le Cat points to the commonality, in nature, of fire. It occurs in the earth, in the heavens through stars and meteors, in phosphorus, and with electricity. Indeed, Le Cat claims, in his "so erudite century," all Europe saw the aurora borealis in 1726, evidence to him of fire occurring in nature without obvious causes. Le Cat identified a number of scholars who believed in spontaneous combustion including, for example, Francis Bacon who "saw the belly of a woman full of sparks." Le Cat includes numerous cases that enabled him to suggest the frequency and geographic breadth of this problem. A priest, Père Richer, visited an underground grotto in Rome and saw sparks emanating from the head of his companions, overheated by the walk. The physician Johann Daniel Horstius, wrote about a man named Antoine Godefroy who suffered from gout; Godefroy claimed that after a particularly violent bout of the disease, he could rub his limbs and they would be "resplendent with light." Horstius also cited a woman

16 Sigaud de la Fond 1781, II, 238-239, citation from 248.

17 On Le Cat see Louis 1859; Vetter 1969; Sapori 2005.

18 Voltaire, quoted in Artigas-Menant 1991, 346.

19 On his communications to the Académie de Rouen see Lemercier 2001, 166; on his presentations on spontaneous combustion also see Segal 2001. For his work on urology, cataracts and in other areas see Grise 2001; Hossard 1970; Berteau 2001.

20 Berteau 2001 and Martin 1958.

21 Louis $1859,146$. 
who, one day when very angry, appeared to have flames all around her head. Another seventeenth-century physician, Ezechiel à Castro, wrote about the countess Cassendre Buri from Verona whose shoulders shone with a luminescence after they had been rubbed with a handkerchief. Mizzanchelli, a medical doctor from Milan, described a man who awoke to find his wife's body covered with a flame that moved about her body. Finally, after about fifteen minutes, the flame disappeared without having caused any damage. Giovanni Borelli, a seventeenth-century Italian savant, apparently reported a case in which flames appeared on a peasant when he was exposed to air. This was similar, Le Cat thought, to the kind of phosphorus common around Hamburg. ${ }^{22}$

Having satisfied himself regarding the legitimacy of his subject, Le Cat then turns to a narration of all the cases he could find that scholars had labeled spontaneous human combustion. Not all of these examples held equal weight. In some instances he found considerable information available while at other times little information presented itself. Le Cat lists a number of famous examples including the Countess Cornelia Bandi and Grace Pitt for both of whom a fair amount of detail emerged from people present immediately after their deaths. ${ }^{23}$ Bandi died in 1731 at the age of sixty-two in Cesena while Grace Pitt, the widow of a fisherman living in Ipswich, died in 1744 at roughly sixty years of age. ${ }^{24}$ Throughout all the presentation of cases, however, Le Cat's discussion rests entirely on the reports of others. Le Cat was a well regarded physician and surgeon but his status as an expert on this topic rested mainly on his relative proximity to the Millet case and it remains important to remember he was also absent from that case.

Le Cat spends the second part of his treatise outlining the physical causes of spontaneous combustion. The existence of such fires, Le Cat writes, were "proved by the facts." In addition to his earlier references to past scholars and to cases, Le Cat also develops a scientific argument of his own. His explanation centers on the existence of a "fluide caustique" combined with the fat present in the human body and made more combustible due to the ingestion of spirits; it was no accident, Le Cat remarked, "that all the subjects who had perished by spontaneous combustion were extremely fat, or if they were thin, they were drinkers of spirituous liquors". ${ }^{25} \mathrm{He}$ does not have any particular evidence for this fluid other than his belief that something found in the bodies of the deceased must have been especially flammable.

22 Le Cat 1813, 44-46.

23 Le Cat $1813,47-52$.

24 Rolli $1744-1745$.

25 Le Cat $1813,150$. 
The source of the fire need not, Le Cat claimed, come from an external agency. "We have seen," he believed, "a great number of various liquors and of materials which caught fire by themselves and without the approach of any other flame". ${ }^{26}$ As evidence, Le Cat again pointed to phosphorus from Hamburg that ignited when exposed to air. In the case of people, there was a sort of "human phosphorus" composed of various substances and abundantly found in the body. In addition, there is an "inflammatory effervescence" which plays the role of the active "agent for [these] fires." This effervescence is found more in sedentary people of a certain age or decrepitude. The way to avoid falling victim to this malady, concludes Le Cat, is to avoid the "continued use of spirituous liquors." If individuals continued to overindulge, then one could become a "prey to the flames" as a result of their drunkenness and as a punishment for their vices. ${ }^{27}$ Le Cat, then, draws his information largely from case studies and his knowledge of physiology. Drinking and laziness contributed most directly to this phenomenon.

The other major author writing on this topic, Pierre-Aimé Lair, did not let a dearth of cases prevent him from writing at length about the causes and effects of spontaneous combustion. Drawing on the work of Le Cat, Lair's book, Essai sur les combustions humaines, produites par un long abus des liqueurs spiriteuses, appeared in 1800 and attempted to describe the potential causes inherent in the victims while also examining the remains. ${ }^{28}$ The result is a social and cultural understanding of those individuals who might fit the profile of future victims. Lair had studied medicine, although he never practiced or took a degree. Instead, after some time traveling, Lair settled in his native Caen where he belonged to local societies including the Société Linnéenne and the Société d'agriculture et de commerce. Lair wrote on a number of topics including agriculture, some biographies, and descriptions of Cherbourg and Boulogne-sur-Mer.

In his Essai, Lair outlined eight common attributes that connected those people who had died as a result of this affliction. Lair's first commonality identifies victims as "having, for a long time, abused spirituous liquours". ${ }^{29}$ When trying to explain the sudden appearance of fire, Lair went directly to an obvious method for the flames to spread inside the body. In addition, that Lair starts with alcohol abuse reveals something of a tone of morality and offers an ethical explanation for the events. In addition, and even more vehemently than Le Cat, Lair is seeking an acceptable and concrete explana-

26 Le Cat $1813,151$.

27 Le Cat 1813, 153-154.

28 Lair 1800.

29 Lair 1800, 37-38; see Carol 2001, 142-143. 
tion for the fires. The people who died did so due to the presence of flammable liquids that saturated their bodies and, at least in part, because of their own weakness. Indeed, the subtitle of Lair's book explicitly articulates his moralistic view and makes unsurprising his initial focus on the abuse of alcohol. Lair goes on to outline, in as much detail as was available, the drinking habits of the victims. An unnamed woman mentioned in the Actes of Copenhagen had, "for three years, abused strong liquors." Madame Millet "was drunk without cease" while Madame de Boiseon "drank nothing, for several years, except eau-de-vie". ${ }^{30}$ Lair's belief in the connection between spontaneous human combustion and alcohol abuse was echoed in the nineteenth century by such writers as Robert Macnish in his book The Anatomy of Drunkenness although Macnish admits the relationship between the alcohol found in the bodies of drunkards and its ability to sustain combustion was "not easy to determine". 31

Lair goes on to offer his analysis of why heavy drinkers were more likely to spontaneously combust. First, he noted that those who drank heavily ate little and even had repugnance for certain foods such as legumes and fruit, and a "near horror for water." Instead, they eat highly salted beef and ripe cheeses. The combination, Lair claims, of excessive alcohol with spiced, rich foods essentially transforms the body. Since alcoholics do not urinate as often as non-alcoholics, or so Lair believes, the alcohol stays in the body. U1timately, the victims "muscles even are impregnated with alcoholic substances." To substantiate these claims, Lair cites a case from Caen from the 1790s in which a solider called Colin was dissected after having died in a duel. Noted for being a constant drunk during life, Colin's body in death emitted "a spirituous odor." Overweight drunks were even more likely to go up in flames. While a drunk's muscles might absorb a considerable amount of liquor, the fat of drinkers was particularly "soft, flabby, [and] oily," especially in women..$^{32}$ Concerns about alcohol consumption, and particularly gin and chiefly among the poor, were common in the eighteenth century, especially in Great Britain. ${ }^{33}$

The relationship between alcohol and spontaneous human combustion appeared in the arguments presented by other writers. A case discussed by Johann Heinrich Cohausen, a physician known for his medical satires, appeared in his Lumen novum Phosphoris accensum (Amsterdam, 1717), a book cited by the Philosophical Transactions. Cohausen claimed a "Polish

30 Lair 1800, 39-40.

31 Macnish 1835, 82. On drinking in early modern France in general see Brennan 1988.

32 Lair 1800, 42-42 (Colin), 41-42 (on muscles) and 45 (on women).

33 Porter 1995, 418-419. 
Gentleman, in the Time of the Queen Bona Sforza, having drank two Dishes of a Liquor called Brandy-wine, vomited Flames and was burnt by them". ${ }^{34}$ Le Cat also commented on the rumor that Grace Pitt had drank a lot of liquor on the night she died although he offers the comment that her exuberance was caused by the news of the return of one of her daughters from Gibraltar. Thus, he does not depict Pitt as a habitual drunkard but a victim of circumstance. ${ }^{35}$ Thus, some differences of opinion existed regarding the reason why victims tended to have overindulged in liquor although everybody agreed that the flammable nature of alcohol caused the immediate problem.

This leads to Lair's second observation that, as a general rule, women were the victims of this phenomenon. He acknowledged, of course, the possibility that men might "equally be exposed to combustion," but then added he "could not discover a single well-certified example". ${ }^{36}$ Lair believed, for a variety of reasons, in the increased likelihood of women suffering this fate. Many of these rationales drew on medical notions of women stretching back centuries but tied with recent innovations in their constantly changing stereotype. Thus, Lair avers, "the bodies of women are in general more delicate than those of men" and "their fibers more spindly and of a structure less firm" allowing them to fall apart more easily. In addition, Lair added, women are "more sedentary" and stayed more frequently in the interior of the house, regularly in closed chambers "where they often find themselves condemned to pass entire days without taking any exercise" and so are more likely than men to become overweight. This makes women's bodies more "spongy" allowing their entire bodies to "imbibe of spirituous liquors" which leads them to be more likely to burn easily. This characterization of women draws on the much older notion of women as wetter than men who, idealized, were hotter and dryer. ${ }^{37}$ When women's "wetness" shifted from being based in water to alcohol, they became prime candidates for spontaneous combustion. Lair was not alone in his view of women as likely victims. Giovanni Borelli cited an example from the seventeenth century of a woman who "vomited Flames in the Point of Death" as well as how "Fire came out from the privy parts of a woman." Borelli also cited ancient authorities that suggested such accidents happened often to "great Drinkers of Wine and Brandy". ${ }^{38}$

34 Cohausen, cited in Rolli 1744-1745, 450.

35 Le Cat 1813, 51.

36 Lair 1800, 49-50; Carol 2001, 146-147.

37 Lair 1800, 50-51. See the summary of ideas about women in Schiebinger 1989, 161-165; Laqueur 1990, passim.

38 Rolli 1744-1745, 459. 
Lair next turns his attention to the average age of the women. In general, he believed older women more likely to be victims. He points to five cases in which the age at death ranged from forty-eight to sixty-two years in age. While not considered old today, this counted as somewhat elderly for the eighteenth century and, for Lair, proved this phenomenon was more frequent among older women. He claimed young people, by contrast, were far too distracted by "other passions" to need to drink. ${ }^{39}$ The older victims, Lair asserts, drank alcohol to fill the void left by an absence of some other interest or ambition such as love or religious fervor.

Alcohol also became more of an option for those women living "without constraint" by which Lair meant many of the women were single or widowed. Lair cites the case of Mary Clues, a woman living in Coventry, England, who died in 1772 "about a year and a half" after the death of her husband during which time she acquired the habit of drinking about "four half pints of rum, undiluted with any other liquid, in a day". ${ }^{40} \mathrm{Age}$, according to Lair, also caused people to lead a more sedentary lifestyle that could result in an excess of very flammable hydrogen in the body. While young people danced and walked, activities that "formed a beneficial cleansing," at a certain age those activities were forbidden either "by nature or by prejudice". ${ }^{41}$ Such people, immobile due to age, laziness, obesity or drunkenness, are more susceptible to the effects of combustion. Le Cat, like Lair, also provided examples of elderly victims, including a lady named de Boiscon from Dinan in the north of France who was around eighty years old and who continued to drink a large quantity of eau-de-vie each day. ${ }^{42}$

Lair took it as axiomatic that older, alcoholic women would be more likely to spontaneously combust. What puzzled Lair was the nature of the fire: was it truly spontaneous or was there an external cause? Lair noted that drunks have "spirituous emanations" coming from their mouths that "must be very flammable". ${ }^{43}$ These emanations are linked to the contents of the stomach, which was full of liquor. Thus, a lamp or candle flame could easily ignite the vapors and lead to combustion. As evidence, Lair cites a case from Caen, as reported by Abbé Adam, most famous for being one of the early teachers of Pierre-Simon Laplace and for his popular lectures that still promoted Aristotelian natural philosophy long after Cartesian and Newtonian

39 Lair 1800, 52.

40 Lair 1800, 53; see Wilmer 1774, 340.

41 Lair $1800,54$.

42 Le Cat 1813, 56. Curiously, women associated with spontaneous combustion shared some characteristics with women accused of witchcraft (age, gender, and a certain immorality, in this case drunkenness). On this topic see Shaw 1995; Warner 1996.

43 Lair 1800, 56. 
ideas had become vogue. ${ }^{44}$ Adam reports that a drunken woman had leaned forward to blow out a candle; the flame, however, ignited her breath, entered her body, and burned her. Perhaps, Lair suggests, investigators should not look too far for the causes of these accidents. Any source of fire could ignite someone's clothes, burn them, and in turn burn those women with a particular disposition, by which Lair meant older, alcoholic women. The effects of alcohol on the rapid combustion of an object, including a human, were so obvious to Lair that he wrote "it is useless to cite other examples." Having written that, however, he then goes on to point out that there may have been some cases, such as those cited by Le Cat, in which the combustion was not accidental but spontaneous..$^{45}$ On this point, then, Lair tends to waffle.

Lair defines spontaneous combustion as a blaze which consumes the human body without any external source for the flame. Like Le Cat and others, he points to numerous natural examples from the mineral and vegetable kingdoms. ${ }^{46}$ Other authors also illustrated the existence of spontaneous combustion of things other than humans. As mentioned earlier, Sigaud de la Fond described how the village of Boncourt caught fire "without any apparent cause". ${ }^{47}$ Even after examining these cases, however, Lair suggests that "accidental combustion seems easy to prove" while spontaneous combustion "presents an improbability." Nonetheless, Lair concludes that "if one cannot find any trace of fire in the area where the combustion had taken place," then he would have "faith in the existence of spontaneous combustion." Faith is hardly a scientifically relevant argument at the end of the age of Enlightenment and Lair hedges his bets saying if you look hard enough, you will always find some external source for the fire. He adds that sometimes the fire lasted a long time, which meant that the flame causing the body to combust may have long since died out even as the victim continued to burn. In the end, Lair regards spontaneous combustion as "impossible". 48 This conclusion goes against that of many of his predecessors, including Le Cat, who firmly believed in the reality of spontaneous combustion.

The fifth similarity among victims of spontaneous combustion had to do with how much of their bodies had been burnt and, even more importantly, which parts were not burnt. Frequently, Lair and others noted, the "extremities of the bodies of these women had been spared by the fire." The bones at the extremities are harder, Lair argues, while those near the trunk are

44 Hahn 2005.

45 Lair 1800, 56 (on Adam) and 60 (on causes).

46 Lair 1800, 60-63. Also see Sigaud de la Fond 1781, II, 238-256.

47 Sigaud de la Fond 1781, II, 248.

48 Lair 1800, 63 (on improbability), 64 (on faith) and 66 (impossibility). 
soft and, therefore, burn more easily. This also reinforces the idea of the flame starting inside the body, near the center, and working their way out. A sixth commonality centers on the nature of the flames; sometimes, writes Lair, when water is used to try and extinguish the flame in those parts of the body still burning, it does not have any effect ${ }^{49}$ Lair explains this by noting that alcohol, mixed with water, still burns. This hearkens back to the level of alcohol in the bodies of the victims that, Lair believes, is quite high because of their drunkenness.

While the fire tends to consume much of the victim's body except, as noted above, the extremities, it does not do much damage to the surrounding area. Clothes, furniture, flooring, etc. tend to remain fairly intact in spite of the great heat required to burn a body almost into oblivion. Lair's seventh observation seeks to explain this situation. In one case, that of Grace Pitt, observers discovered an infant's clothes and a scrap of paper near the body, both undamaged. ${ }^{50}$ Lair argues that this proves the "fire which emanates from drunkards is of a particular nature, that, in destroying their bodies, often spares neighboring objects". ${ }^{51}$ The fire seems to burn hotter, but also in a very contained way. The alcohol that served as the fuel for the fire was inside the body; thus, bodies tended to burn inside out with much of the combustion happening internally. Lair's last observation is that the combustion of these bodies leaves a residue, "of fatty and fetid ashes" or a sort of "unctuous soot, stinking and very-penetrating." All the objects in Marie Clues' room, for example, had been blackened and the room was dominated by a "very disagreeable vapor". 52

The effects of the fires receive considerable attention in the accounts. This includes both a description of the body, or more accurately the remains of the bodies, as well as the surrounding objects. In the case of Bandi, for example, the body was in a "deplorable Condition," with "two Legs untouch'd, from the Foot to the Knee, with the Stockings on; between them was the Lady's head; whose Brains, Half of the Back part of the Scull [sic], and the whole Chin, were burnt to Ashes; amongst which were found three Fingers blacken'd." Besides these bits and pieces "all the rest was Ashes" of a quality which was particularly "greasy and stinking." The stench and the soot covered much of the room and even nearby rooms. The ashes had even traveled into the kitchen where it "hung on the Walls, Moveables, and Utensils." A piece of bread was covered with soot and had turned black; people

49 Lair 1800, 67 (on extremities) and 68-69 (on the nature of the flame).

50 Lair 1800, 71.

51 Lair 1800, 72 .

52 Lair 1800, 39 (on residue) and 73 (vapor). 
there attempted to give it to several dogs, all of whom, wisely, "refused to eat it". ${ }^{33}$

Le Cat, Lair and others readily identified a number of social and cultural traits that unified the deceased. However, while they selected categories that supported their overall opinions, they also ignored other issues. Interestingly, the victim's social circumstances rarely come specifically under discussion. While the women are often described as older and significant drinkers of alcohol, their social status, often among the lower economic levels, but not from the peasantry, is not discussed. As with the other commonalities tying the victims together, there are exceptions to this rule; one of the older women who died was the countess Cornelia Bandi. ${ }^{54}$ In Bandi's case, however, there is no mention of a spouse. Her maid discovered her in the morning; as either a single or widowed woman, she still fits the stereotype of potential victims. Similarly, Mademoiselle Thuars is not listed as having any occupation, but she is described with more formal language. Thuars, who was over the age of sixty, apparently was "extremely fat," and "very devoted to wine and liquors" ${ }^{55}$ However, one of the first victims typically discussed, from the seventeenth century, was unnamed and described simply as "a woman of the people" or "a poor woman of Paris". ${ }^{56}$ Thus, she is of the lower classes, but lived in an urban environment. Grace Pitt was the wife of a fish merchant and Millet the wife of an innkeeper. Marie Jauffret, who died in 1779, was the widow of a cobbler and another victim, unnamed, was simply "an old drunk woman." In other cases, the status of the individual is unclear; one victim was "a women of about 50 years of age," while another was described simply as a "woman from Paris". ${ }^{57}$ Mary Clues was "of indifferent character" but no other specific reference to her status was offered although apparently she was a widow and wealthy enough to afford four half pints of rum each day. ${ }^{58}$

None of the authors discussing spontaneous combustion make much of the fact that this was an urban phenomenon. There do not seem to be any rural cases. Perhaps this has something to do with the overall view of the victims; obesity was certainly not a rampant problem among peasants, even in the relatively stable eighteenth century, and the victims were often described as somewhat overweight. Similarly, the ability to abuse alcohol, and to be

53 Rolli 1744-1745, 447-448.

54 Heilbron 1994. Another countess is mentioned by Le Cat although she does not die; instead, her skin lights up when rubbed with a cloth. See Le Cat 1813, 45.

55 Lair 1800, 2.

56 In Lair 1800, 10, she was "une femme du people.” In Rolli 1744-1745, 450, she was a "poor woman at Paris."

57 Lair 1800, 34 (on Jauffret and the drunk woman) and 18-19 (old woman of Paris).

58 Wilmer 1774, 340-343. 
sedentary enough to not burn it out of your system, may also have been considered an urban problem rather than a rural issue. People certainly drank in the countryside, and probably did so to excess, but it may have been believed that they also tended to work hard which, in the eyes of the commentators, would have helped expel any excess alcohol from their systems.

One of the few people to mention the status of victims was Lair, albeit obliquely and briefly. Toward the end of his treatise Lair grapples with the possibility that someone might argue these deaths were not accidents but the result of murder. Assassins could, he hypothesized, seek to eradicate all traces of their crimes by soaking their victims with some sort of flammable liquid and igniting it. However, Lair adds, such a method of killing hardly seems possible. In any case, all the people about whom Lair wrote, "were nearly all of a condition little suitable to excite greed." He mentions three examples in particular: first the "woman of the people" reported in 1672; second, the wife of the fish merchant, and third, a cobbler's wife. Other cases, he wrote, also came from "the most inferior class of society." Thus, Lair concludes, spontaneous human combustion was "always accidental and never intentional" and, in general a lower class problem. ${ }^{59}$

While the social status of the victims is worth discussing, the status of the witnesses reporting the cases also proves interesting. Was this something they had seen personally or something they had heard about from a second source? Their position vis-à-vis the events as well as their own station in life helped contributes to their overall reliability. This is where things get somewhat problematic for supporters of spontaneous combustion. While a few professional medical men were involved in some cases, at least in a peripheral way, the immediate source for their information tended to come from people without an obvious scientific background. The ability of savants in early modern Europe to assert authority for their opinions depended, in large part, on how their readers might interpret their trustworthiness. ${ }^{60} \mathrm{In}$ some cases, that status derived from one's lineage; aristocrats did not hold a monopoly on truth, but the truth-status of their claims did hold more weight because of their nobility. Similarly, membership in a respected society, such as the French Académie Royale des Sciences or, in England, the Royal Society of London, helped contribute to the ways that the general public understood their reliability and trustworthiness.

In the nineteenth century, Alphonse Devergie made a point of indicating who had initially reported any particular case. ${ }^{61}$ Thus, of the twenty cases he

59 Lair 1800, 77-78.

60 See Shapin 1995; Goldgar 1995.

61 Devergie 1852, II, 806-807. 
explores, two originate from his reading of Le Cat, one from Félix Vicqd'Azyr, and so on. However, these were the individuals who published information on the topic; they were not witnesses to the event - nobody ever claimed to witness it personally - or even direct witnesses of the aftermath of spontaneous human combustion. This brings us back to Le Cat who reported extensively on the case of Millet with whom he had once lived. However, when Jeanne Lemaire died, Le Cat was not there. Instead, he received his information from the local surgeon. This sort of second hand information is typical. At no point are there any accounts of someone watching anybody dying of spontaneous combustion. Apart from a few oft-repeated anecdotes, there were no witnesses to the actual event. Similarly, the people who reported these events were not present at the death or even always after the death. Oftentimes, they got their information from some allegedly reliable source present at the scene. As such, even when Le Cat discussed earlier reports of spontaneous human combustion and similar events, he made a point of referencing the status of the reporters and the witnesses. Thus, one case came from a man named Valisniere, who was a friend of the marquis Scipion Maffey and who published a letter based on a report of the doctor Mizzanchelli from Milan. Rather than just mention the letter, Le Cat provides a sort of provenance of its authoritative status. In this case, he established that one source was a doctor and the other a friend of a nobleman. ${ }^{62}$

Lair also made a point of listing who had reported on cases of spontaneous human combustion. "Bianchini, Maffey, Rolli, Le Cat, Vicq-d'Azyr, and many distinguished savants," Lair write, "have provided excellent testimonies". ${ }^{63}$ Lair was particularly pleased that Vicq-d'Azyr, in his entry for the Encyclopédie Methodique, medicine, included a short section on this topic in which he describes a "woman from Coventry" aged fifty who "abused spirituous drinks" and spent her days lying in bed. As a result, she was entirely burnt and reduced to ashes except for the two femurs and some other bones. The fire, Vicq-d'Azyr reported, did no damage to the building or the room. "Newspapers," he added, "contain many facts of this nature, which surpass all belief" ${ }^{64}$ Vicq-d'Azyr, however, devoted only a few brief lines to this topic at the end of a three hundred page entry on anatomy; this hardly counts as an overwhelming approbation. ${ }^{65}$ Nonetheless, Lair and others certainly read it in exactly that way drawing on Vicq-d'Azyr's status as a doctor to buttress their own

62 Le Cat $1813,46$.

63 Lair 1800, 9.

64 Vicq-d'Azyr 1787, 544.

65 Lair's summary of Vicq-d'Azyr's findings was fully as long as the original entry; see Lair $1800,18$. 
views. Vicq-d'Azyr had earned a significant reputation as a comparative anatomist at the end of the eighteenth century, taught public courses at the Jardin du Roi and the Musée de Monsieur, and was a member of the Académie Royale des Sciences. ${ }^{66}$ Thus, even a mention from him might appear positive.

The lack of direct witnesses presented a significant problem for Le Cat and Lair. They responded by emphasizing the status of those people who had reported cases, a strategy that helped provide some strength to their arguments but which in no way replaced the need for actual witnesses. That spontaneous human combustion bordered on the wondrous, as evidence from its inclusion in Sigaud de la Fond's Dictionnaire des merveilles, certainly did not help matters. As Palmira Fontes da Costa has argued for Great Britain, discussions of matters deemed extraordinary required special literary strategies in order to establish their veracity. ${ }^{67}$

In a few cases, the person who reported the death was also there to personally examine the corpse. Wilmer, the surgeon who reported to England the death of Mary Clues, certainly writes as if he were there. But more generally the reporter gets the information from someone at the scene. This indirect method of learning what happened was augmented, in Le Cat's case, by his personal knowledge of the people but not by his presence at the time of the event. Thus, Lair emphasized that Chrétien was there himself to examine the remains of the body "with all the legal formalities". ${ }^{68}$ This helps give more authority to Chrétien's testimony as well as Le Cat and Lair's reliance on that testimony. At a time when observation was increasingly important, this sort of second-hand information was the best they could expect. But much of the information provided summarized accounts of the individual's lifestyle prior to their demise, information that may or may not have been medically relevant much less accurate.

Most often, however, the people reporting the cases derived their information from other sources, typically local medical practitioners - including surgeons and pharmacists - as well as local clergymen. The local pharmacist, a man named d'Aumenil, reported the death of Thuars in Caen. In this case, however, d'Aumenil's report on the case was, Lair suggested, very similar to another case in Caen reported by the surgeon Mérille. The implication was that d'Aumenil simply copied his report from Mérille's. ${ }^{69}$ Several people reported some deaths although it was unclear if any of them had ac-

66 Lynn 1999.

67 Fontes da Costa 2002, 265-288. On wonders more generally see Daston and Park, 1998; Schaffer 2018.

68 Lair 1800, 23.

69 Lair 1800, 32-33. 
tually seen the body, known the deceased, or had any real evidence for their assertions. Many people, for example, apparently mentioned one of the cases from Caen, but Lair emphasizes only one name, that of a doctor from d'Argentan named Bouffet who had written a book on fevers. However, there was no suggestion that Bouffet had any personal experience in the case. Possible Lair simply made sure to mention the person with the greatest medical experience or highest status in order to give more weight to the example. Le Cat gets one of his examples from a priest named Bonnar living in Plergues near Dôle while the Abbé Adam wrote about a woman in Caen. Bonnar also claims to have heard about a case in the same area that had occurred thirty years earlier, information that he deemed reliable since it came from Mademoiselle Duverger-Goyon. ${ }^{70}$

Sometimes the truthfulness of the account derives, at least in part, from the status of the source publication. The case of a poor woman appeared first in the Actes de Copenhague, a source whose veracity later savants never questioned. ${ }^{71}$ Bianchini's printed memoir, excerpted in the English journal the Annual Register, and other places, was accepted without question. He had, according to Lair, "printed the details of this deplorable event, at the time when it happened, and nobody contradicted it." Thus, Bianchini seems to have been nearby at the time; as such, his presentation of the results of the death was deemed accurate. Bianchini was described as a minister and a Prebend in Verona, which may have given him some status. Le Cat refers to him as "the celebrated Bianchini" and claims he is a doctor as well as an ecclesiastic. ${ }^{72}$ The translator of his treatise was Paul (Paolo) Rolli, an Italian writer and a Fellow of the Royal Society, which certainly helped. That this case also appeared in the Philosophical Transactions of the Royal Society provided additional support for the legitimacy of spontaneous human combustion. ${ }^{73}$

The Philosophical Transactions also printed an "Extract of the Minutes of the Royal Society" about Grace Pitt. In this case, the information came from a physician, Dr. Lobb, who was passing on two letters he had received. The first came from a minister, the Reverend Mr. Notcutt who was writing to another minister, the Reverend Mr. Gibbons. The second letter passed the information on from Gibbons to a third, unnamed, individual. Apparently, both Notcutt and Gibbons gave similar descriptions of the event, and both took their information from "the Mouths of the eye-witnesses, who

70 Le Cat 1813, 56.

71 See, e.g., Lair 1800, 10.

72 Le Cat 1813, 47.

73 Rolli $1744-1745,447$. 
viewed the Body." Gibbons claimed he actually talked to the daughter of the victim along with two people who lived in the same house. ${ }^{74}$ This sort of proximity to the case, without being direct witnesses themselves, gave them enough credence that their opinions were taken seriously. That Gibbons and Notcutt were ministers, and that a medical doctor passed the information along to the Royal Society, also played a role in how the information was received. Lair's interpretation of the data focused on what he saw as the "crowd of eyewitnesses" for the event along with the multiple discussions it engendered among savants. Even more important, three different recitations of the event all provided similar accounts. In this way, individual reporters confirmed to Lair, through the similarity of their experiences with the evidence provided, that the details given must be accepted as true. ${ }^{75} \mathrm{He}$ did not question the similarity or suggest the descriptions were the same because they all drew from the same original source.

$* * * * *$

In the nineteenth century, Charles Dickens, Emile Zola, and other writers of fiction used spontaneous combustion as a plot point in their novels in ways that seem to indicate they did not have any quibbles with the reality of a death that took place in this manner. ${ }^{76}$ As mentioned earlier, Charles Dickens included spontaneous combustion in his novel Bleak House, where Krook, the keeper of a rag and bottle show, died in this fashion. ${ }^{77}$ The description of Krook's death comes almost directly from eighteenth-century cases and Dickens makes a point of showing his sources, including Le Cat. Thus, on the night of his death, Krook's neighbors note the air "is not very freshening," (506) and that it tastes "rather greasy" (507). Krook is lower class and has a reputation for drunkenness (512). When two characters, Mr. Weevle and Mr. Guppy, visit him, they comment on the "hateful soot hanging about" (515) and find pouring out of Krook's window "a thick, yellow liquor" which "is offensive to the touch and sight, and more offensive to the smell" (516). They eventually go into Krook's shop and find a small fire in the grate, a "smouldering suffocating vapour in the room and a dark greasy coating on the walls and ceiling." However, the furniture remains untouched as does Krook's hat and coat (517). Eventually, they notice a burnt patch on

74 “An Extract” 1744-1745, 463-464.

75 Lair 1800, 19-20.

76 On Zola see Carol 2001 and Nourrisson 1993.

77 Dickens 1996. 
the floor and the sprinkle of ashes. Krook, they conclude, fell victim to "Spontaneous Combustion, and none other of all the deaths that can be died" (519). ${ }^{78}$

Spontaneous combustion never garnered as significant an intellectual following as did other phenomena such as animal magnetism that reemerged in the nineteenth century to wide appeal. ${ }^{79}$ Even though Dickens, and others, looked back to scholars from the seventeenth and eighteenth centuries for verification of their beliefs, those individuals did not necessarily have unwavering support. Le Cat and Lair, in spite of their efforts, never fully explained to the satisfaction of everybody exactly how spontaneous combustion worked. Here, alongside other faltering attempts to rationalize and make enlightened practices and beliefs that bordered on the marvelous, scholars balanced their pursuit of the Enlightenment ideal and their continuing fascination with wonders. As a result, spontaneous human combustion remained on the edges of traditional scientific inquiry but continued more solidly within the popular and literary imagination.

\section{Bibliography}

Adelson, Lester, "Spontaneous Human Combustion and Preternatural Combustibility", The Journal of Criminal Law, Criminology and Police Science 42 (1952) 793809

Artigas-Menant, Genevieve, "La vulgarization scientifique dans Le Nouveau Magasin français de Mme Leprince de Beaumont", Revue d'histoire des sciences 44 (1991) 343-357

Belhoste, Bruno and Nicole Edelman (eds.), Mesmer et mesmérismes: Le magnétisme animal en contexte (Montreuil 2015)

Benedict, Barbara, Curiosity: A Cultural History of Early Modern Inquiry (Chicago 2001)

Berteau, Pierre, "Le Cat et l'Ecole d'anatomie", Histoire des sciences médicales 35 (2001) 141-150

Blount, Trevor, "Dickens and Mr. Krook's Spontaneous Combustion”, Dickens Studies Annual 1 (1970) 183-211

Bondeson, Jan, A Cabinet of Medical Curiosities (Ithaca NY 1997)

Brennan, Thomas, Public Drinking and Popular Culture in Eighteenth-Century Paris (Princeton MA 1988)

Brockliss, Laurence and Colin Jones, The Medical World of Early Modern France (Oxford 1997)

Carol, Anne. "Zola et la combustion spontanée: de l'usage d'un mythe en médecine", Les cahiers naturalistes 75 (2001) 139-155

78 Other authors also used spontaneous combustion in their novels. See Perkins 1964; Hack 1999.

79 See Winter 2000. 
Darnton, Robert, Mesmerism and the End of the Enlightenment in France (New York 1970)

Daston, Lorriane and Katherine Park, Wonders and the Order of Nature, 1150-1750 (New York 1998)

Denman, Peter, “Krook's Death and Dickens's Authorities”, The Dickensian 82 (1986) 130-141

Devergie, Alphonse, "De la combustion humaine spontanée", in Devergie, Médicine légale, théorique et pratique, 3 vols. (Paris 1852) II, 795-836

Dickens, Charles, Bleak House (New York 1996)

"An Extract of the Minutes of the Royal Society", Philosophical Transactions 43 (1744-1745) 463-464

Fontes da Costa, Palmira, "The making of extraordinary facts: authentication of singularities of nature at the Royal Society of London in the first half of the eighteenth century", Studies in the History and Philosophy of Science 33 (2002) 265288

Gaskell, E., "More About Spontaneous Combustion”, The Dickensian 69 (1972) 2535

Goldgar, Anne, Impolite Learning: Conduct and Community in the Republic of Letters, 1680-1750 (New Haven 1995)

Grise, Philippe, "Claude-Nicolas Le Cat (1700-1768), un grand nom de la Chirurgie et de l'Urologie au 19ème siècle", Progrès en Urologie 11 (2001) 149-153

Hack, Daniel, “Sublimation Strange': Allegory and Authority in Bleak House”, ELH 66 (1999) 129-156

Hahn, Roger. Pierre-Simon Laplace, 1749-1827: A Determined Scientist (Cambridge MA 2005)

Heilbron, John L., "The Affair of the Countess Görlitz", Proceedings of the American Philosophical Society 138 (1994) 284-316

Hossard, Jean, "Le Cat, lithotomiste, et les remèdes de Mlle Stephens", Revue d'histoire de la pharmacie 58 (1970) 155-162

Josephson, C.D., “'La combustion spontanée' dans les oeuvres littéraires ou scientifiques", Acta Medica Scandinavica 65 (1926) 424-442

King, Lester, The Medical World of the Eighteenth Century (Chicago 1958)

Lair, Pierre-Aimé, Essai sur les combustions humaines, produites par un long abus des liqueurs spiriteuses (Paris 1800)

Laqueur, Thomas, Making Sex: Body and Gender from the Greeks to Freud (Cambridge MA 1990)

Le Cat, Claude-Nicolas, "Mémoire posthume de Lecat, sur les incendies spontanés de l'économie animale", Journal de médecine, chirurgie, pharmacie (1813) 39-57, 145-154

Lemercier, Jean Pierre, "Claude Nicolas Le Cat et l'Académie des Sciences, BellesLettres et Arts de Rouen”, Histoire des sciences médicales 35 (2001) 163-168

Lewes, George Henry, "Spontaneous Combustion”, Blackwood's Edinburgh Magazine 89 (April 1861) 385-402

Louis, Antoine, "Eloge de Le Cat": in Eloges lu dans les séances publiques de l'Académie royale de Chirurgie de 1750 à 1792 (Paris, 1859) 129-159

Lynn, Michael R., "Divining the Enlightenment: Popular Science and Public Opinion in Old Regime France", Isis 92 (2001) 34-54 
Lynn, Michael R., "Enlightenent in the Public Sphere: The Musée de Monsieur and Scientific Culture in Late-Eighteenth-Century Paris", Eighteenth-Century Studies 32 (1999) 463-476

Macnish, Robert, The Anatomy of Drunkenness, $5^{\text {th }}$ ed. (New York, 1835)

Martin, Geneviève, "Documents de l'Académie de Rouen concerant l'enseignement des Sciences au XVIIIe siècle", Revue d'histoire des sciences et de leurs applications 11 (1958) 207-226

Nourrisson, Didier, "La combustion humaine spontanée ou la science à l'épreuve de feu", Romantisme (1993) 61-66

Perkins, George, "Death by Spontaneous Combustion in Marryat, Melville, Dickens, Zola, and Others", The Dickensian 69 (1964) 57-63

Porter, Roy, "The Eighteenth-Century". in Lawrence Conrad, Michael Neve, Vivian Nutton, Roy Porter and Andrew Wear (eds.), The Western Medical Tradition: 800 $B C$ to $A D 1800$ (Cambridge, 1995) 371-475

Risse, Gunter, "Medicine in the Age of Enlightenment": in Andrew Wear (ed.), History of Medicine in Society (Cambridge, 1992) 149-195

Rolli, Paul, "An Extract, by Mr. Paul Rolli, F.R.S. of an Italian Treatise, Written by the Reverend Joseph Bianchini", Philosophical Transactions 43 (1744-1745) 447465

Sapori, Michelle, "A la découverte d'un Blérancourtois: Claude-Nicolas Le Cat, Une grande figure de la chirurgie française", Mémoires de la Fédération des sociétés d'histoire et d'archéologie de l'Aisne 50 (2005) 11-41

Schaffer, Simon, "Late Enlightenment Crises of Facts: Mesmerism and Meteorites", Configurations 26 (2018) 119-148

Schiebinger, Londa, The Mind has no Sex? Women in the Origins of Modern Science (Cambridge MA 1989)

Scribner, Vaughn, "'Such Monsters Do Exist in Nature': Mermaids, Tritons, and the Science of Wonder in Eighteenth-Century Europe", Itinerario 41 (2017) 507-538

Segal, Alain, "Claude-Nicolas Le Cat et Reims", Histoire des sciences médicales 35 (2001) 127-131

Shapin, Steven, A Social History of Truth: Civility and Science in Seventeenth-Century England (Chicago 1995)

Shaw, Sheila, "Spontaneous Combustion and the Sectioning of Female Bodies", Literature and Medicine 14 (1995) 1-22

Sigaud de la Fond, Joseph Aignan, Dictionnaire des merveilles de la nature, 3 vols. (Paris 1781)

Vetter, Theodore, "Claude-Nicolas Le Cat: Chirurgien de province au XVIIIe siècle", Annales médicales de Nancy 8 (1969) 433-445

Vicq-d'Azyr, Félix, Encyclopédie Méthodique, medicine (Paris 1787)

Warner, Jessica, "Old and in the Way: Widows, Witches, and Spontaneous Combustion in the Age of Reason", Contemporary Drug Problems 23 (1996) 197-220

Wilkerson, Ann, "Bleak House: From Faraday to Judgment Day", ELH 34 (1967) 225-247

Wilmer, "An Account of a woman accidentally burnt to death at Coventry", Philosophical Transactions 64 (1774) 340-343

Winter, Alison, Mesmerized: Powers of Mind in Victorian Britain (Chicago 2000) 